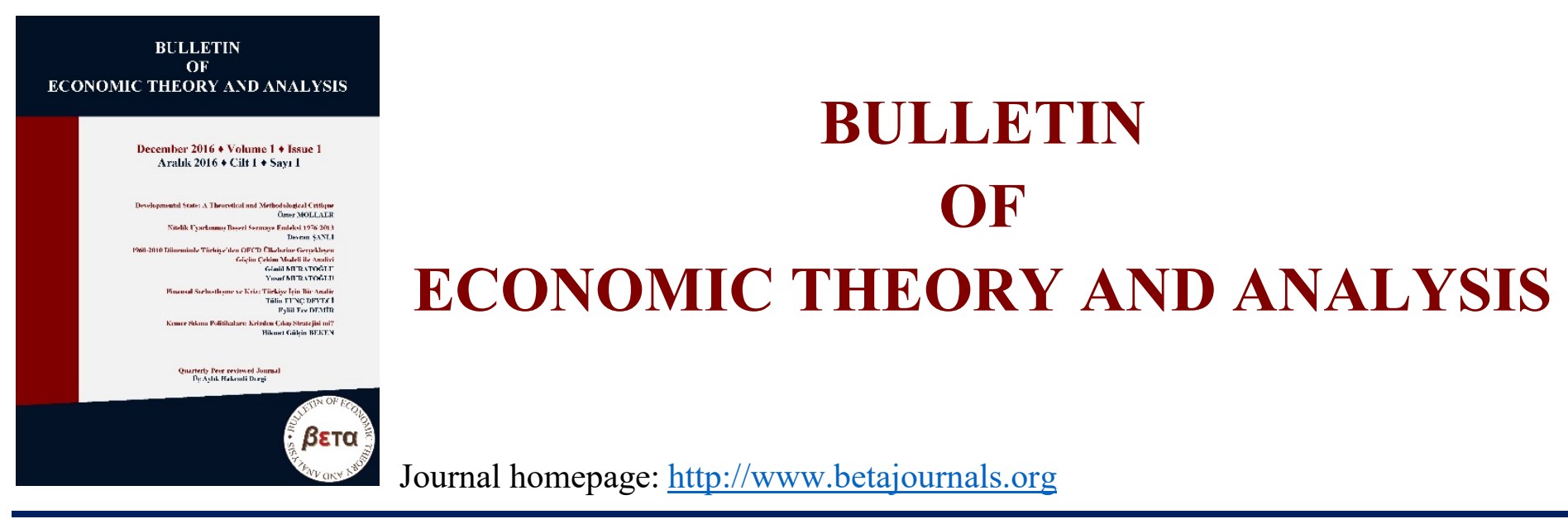

\title{
Pazarlama Faaliyetlerinin Sağlık Sektörüne Uygulanması: Bir Literatür İncelemesi
}

\section{Rojan GÜMÜŞ @ https://orcid.org/0000-0001-8113-6193}

To cite this article: Gümüş, R. (2018). Pazarlama Faaliyetlerinin Sağlık Sektörüne Uygulanması: Bir Literatür İncelemesi. Bulletin of Economic Theory and Analysis, 3(4), 217-235.

Received: 21 Oct 2018

Accepted: 18 Nov 2018

Published online: 30 Dec 2018



(C)All right reserved 


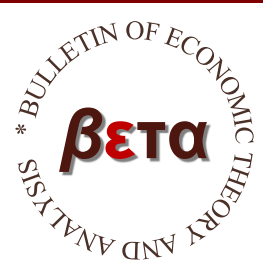

\title{
Bulletin of Economic Theory and Analysis
}

Volume III, Issue 4, pp. 217-235, 2018

http://www.betajournals.org

\section{Pazarlama Faaliyetlerinin Sağlık Sektörüne Uygulanması: Bir Literatür İncelemesi}

\author{
Rojan GÜMÜŞa \\ a Dr.Öğr.Üyesi, Dicle Üniversitesi, Atatürk S.H.M.Y.O., Diyarbakır, TÜRKIIYE
}

\section{ÖZ}

Sağlık sektöründeki rekabetin artışı, teknolojik gelişmeler ve tüketicilerin bilincinin artması tüm sağlık kurumları yöneticilerinin pazarlama biliminden yararlanmasını zorunlu kılmıştır. $\mathrm{Bu}$ çalışma sağlık sektöründe yapılan pazarlama faaliyetlerinin tüketici davranışına etkisini, marka bağlılığı ve marka güveni ile arasındaki ilişkisini araştıran ve ortaya koyan çalışmaları incelemiş ve ortak sonuçlara ulaşmaya çalışmıştır. Tanımlayıcı tipteki bu çalışmanın evrenini Dicle Üniversitesi kütüphanesi veri tabanına kayıtlı 102 çalışma oluşturmaktadır. Araştırma kapsamına alınacak çalışmalar taranırken, "sağlık, kullanıcı, hasta, tüketici, memnuniyet, pazarlama" anahtar kelimeleri kullanılmıştır. Çalışmaya ölçütlere uygun 30 makale dahil edilmiştir. Araştırmanın bulgularına göre, sağlık hizmetlerinde en önem verilen konu hizmetleri sunan personelin davranışı ve ilgisidir. İkinci en önem verilen konu sağlık kurumlarında sunulan hizmetlerdir. Hastanelerin fiziksel yapısı ve tanıtım için yapılan faaliyetler en önemli diğer faktörler arasındadır. Sağlık kurumlarındaki fiyatların ve süreçlerin son sıralarda geldiği çalışmalarda yaş grupları ve cinsiyet gibi demografik değişkenlerin hasta tercihlerini etkilediği bulunmuştur.

\author{
Anahtar Kelimeler \\ Pazarlama, Sağlık, \\ Hizmet, Hastane, \\ Tüketici \\ JEL Kodu \\ I11, M31, P46
}

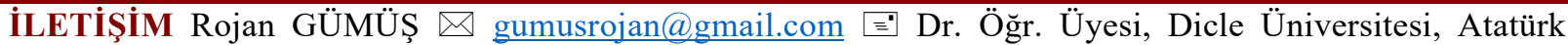
S.H.M.Y.O., Diyarbakır, TÜRKIYE @ https://orcid.org/0000-0001-8113-6193 


\section{Marketing Practices in Health Sector: A Literature Review}

\begin{abstract}
Due to increase in competition at health sector, awareness of consumers and technologic improvements, health professionals were constrained to use marketing tools in order to be successful. This study focused on articles investigated effect of marketing activities on consumer intentions and its relationships between brand loyalty and brand trust in order to reach common results on this issue. In this descriptive research, 102 articles were investigated on database of Dicle University Library and 25 of them were found suitable for the study. During searching articles "health, health marketing, patient, consumer, satisfaction "were used as keywords. According to the findings of the study health consumers focus on empathy and interest of people working in hospitals. The second important issue for consumers is quality of goods and services in the hospitals. Also advertising companies and promotions are important for health service users. For health consumers prices in hospitals and process of activities are not as important as other issues. It was found that different demographic groups had different priorities while choosing e health institute.
\end{abstract}

\author{
Keywords \\ Marketing, Health, \\ Service, Hospital, \\ Consumer \\ JEL Classification \\ I11, M31, P46
}

\section{Giriş}

İşletmeler karlılığını sürdürmek ve hayatta kalmak için mal ve hizmet üretmek ve/veya kullanmak zorundadırlar. Bu mal ve hizmetler ise onların üretildiği piyasalardan sağlanır. Piyasa, herhangi bir malın alıcı ve satıcılarının alım satım akdini gerçekleştirecek kadar sık ilişkide bulunmalarını sağlayan herhangi bir mekanizmadır. Pazar ise bir ürünün fiili ve potansiyel alıcılarının oluşturduğu gruptur. İşletmelerde pazarlama kavramı Pazar ile aralarında sağlam köprüyü kurabilmeleri, diğer bir ifadeyle yaşamlarını idame ettirebilmeleri için gerek duydukları dışa açık bir fonksiyon olarak Pazar sözcüğünden türemiş̧ bir kavramdır (Kotler, 2000; Mucuk, 2016).

\subsection{Sağlık Hizmetlerinde Pazarlama Faaliyetleri}

Pazarlama müşterilerin gereksinimlerini ve beklentilerini anlama ve bu çerçevede hizmetlerin nasıl tasarlanıp sunulabileceğini planlama işlemidir. Pazarlama bir ürünün ortaya koyulması, sonra bu ürünün piyasa şartlarına göre fiyatlandırması, tüketiciye ulaştırılması son olarak da piyasada ürünü tutundurmayı sağlama sürecidir. Pazarlama mal, hizmet ve fikirlerin tüketicilerin şu anki ihtiyaçlarını tatmin etmek ve gelecekte olabilecek ihtiyaçlarını da tatmin 
etmek ve yaratmak üzere ar-ge, fiyatlandırma, tutundurma ve dağıtım faaliyetlerinin planlanması ve yürütülmesidir.

Pazarlama örgütün amaçlarını gerçekleştirmeye yönelik diğer işletme işlevleri ile uyumlu olması gereken bir sistemdir. Pazarlama, kar amaçlı işletme ve örgütler dışında okullar, hastaneler, vakıflar, siyasi partiler ve spor kulüpleri gibi kar amaçlı olmayan sosyal örgütleri de kapsar niteliktedir. Günümüzde tüm sektörlerde olduğu gibi sağlık sektöründe de teknolojideki gelişmeler, sağlık kurumlarının sayısının gün geçtikçe artması, tüketicilerin bilinçlenmesi, sağlık kurumları yöneticilerini de sağlık hizmetleri pazarlamasını profesyonelce düşünme ve planlama yoluna sevk etmiştir (Tengilimoğlu, 2016).

İşletmenin iki temel fonksiyonundan biri olan pazarlama fonksiyonu üretim fonksiyonu kadar önemlidir. Günümüzde, üreticiler arasındaki uzaklık gittikçe büyümekte ve iş hayatında tüketicilerin önemi artmaktadır. Bu yeni duruma uyabilmek için tüketicilerin yakından tanınması bunların istek ve ihtiyaçlarına uygun mamullerin üretilmesi ve üretilen mamullerin tüketicilere ulaştırılması gerekir. Üretim, mal veya hizmetlerin nasıl ortaya konulacağı işlevini; pazarlama ise hangi ürünlerin yani neyin, ne zaman, hangi miktarlarda üretilmesi gerektiğini belirleyen ve bunların ihtiyaç duyulan kesimlere nasıl ulaştırılacağını üstlenen ve birbirlerini tamamlayan temel işletme fonksiyonlarıdır.

Pazarlama kapsamına mal yâda hizmetlerin tüketici ya da kullanıcının ihtiyaç duyacağı zamana kadar korunması ya da depolanması (zaman faydası), mal ve hizmetlerin fazla üretildiği yerlerden diğer bölgelere ulaştırılması ve taşınması (yer faydası), mal ve hizmetlerin üreticilerden ihtiyaca olanlara aktarılması (mülkiyet faydası) gibi faaliyetler girmektedir (Mucuk, 2016)

Bugün pazarlamanın sadece kar amacı güden kuruluşlara özgü olmadığı; dernekler, örgütler, politikacı ve sanatçı gibi kişiler bakımından da söz konusu olabileceği kabul edilmektedir. Ayrıca pazarlamanın sadece mal ve hizmet değişimiyle ilgili olmadığı, bir fikrin yâda sosyal içerikli etkinliklerinde pazarlamaya konu olabileceği düşünülmektedir. Örneğin, aile planlaması, okuma yazma seferberliği yâ da sigaraya karşı geliştirilen kampanyalar gibi.

Sağlık hizmetlerinde pazarlamasında bilinen tüm pazarlama yöntemlerinin kurumların başarısında çok etkisi vardır. İlişkisel pazarlama, bütünleşik pazarlama, sosyal pazarlama, dijital 
pazarlama ve ağızdan ağza pazarlama gibi pek çok yöntemle sağlık kurumları hizmetlerini tanıtma ve kullanıcılarının nabzını tutma işlemlerini gerçekleştirirler.

Pazarlamanın temel işlevi, müşterilerin gereksinimlerini ve beklentilerini anlama ve bu çerçevede sunulacak hizmetleri planlanmasıdır. Ziethaml vd.'ne göre, pazarlama karması stratejisi pazarlama teorilerinin en önemli kavramıdır. Pazarlama yöneticileri bir ürünü pazarlarken, ürünün nitelikleri, fiyatı, dağıtım kanalları, promosyon ve diğer pazarlama unsurlarına ilişkin işletmeyi örgütsel amaçlarına ulaştıracak en doğru faktörleri seçerek bir pazarlama karması oluştururlar. Pazarlama stratejileri geliştirilirken her bir pazarlama karması elemanları göz önüne alınmalı ve her bir alanda alt stratejiler geliştirilerek kararlar verilmelidir (Ziethaml vd., 2000).

\subsection{Sağlık Hizmetlerinde Pazarlama Karması Elemanlarından Faydalanma}

Tüm diğer sektörlerde olduğu gibi sağlık hizmetleri pazarlamasında pazarlama karması elemanlarının önemi tartışılmazdır. Pazarlama karması kavramı ilk olarak Journal of Advertising Research dergisinde Neil Borden tarafından yayınlanmış olan 'The Concept of Marketing Mix' adlı makalede kullanılmıştır. Ürün, fiyat, dağıtım ve tutundurma olarak bilinen pazarlama karması Neil Borden tarafından Ürün planlama, ücretlendirme, markalandırma, dağıtım kanalı, kişisel satış, reklam, tanıtımlar, paketleme, gösteri, hizmet verme, insan gücü ve analiz gibi 12 bileşenden oluşan bir karma olarak tanıtılmıştır. Pazarlama Karması kavramının bir pazarlama modeli olarak kavramsallaştırılması McCarthy tarafından yapılmıştır. 1960'lı yıllarda McCarthy bu bileşenleri sadeleştirerek bilinen dörtlü karmayı oluşturmuştur. Daha sonra Booms ve Bitner (1981) pazarlamanın 4P'sine İnsan, Süreç, Fiziksel Kanıtlar bileşenlerini ekleyerek 7P kavramını oluşturmuştur (Booms \& Bitner, 1981; McCarthy, 1960; Borden, 1964).

Ürün ve Hizmetler: Tengilimoğlu sağlık hizmetleri pazarlaması değişkenlerinden “ürünü” şu şekilde tanımlamıştır: Somut olan mallar; tıbbi araç ve gereçler, tıbbi cihazlar, laboratuvar malzemeleri, ilaçlar, tedavi malzemeleri, protez gibi elle tutulup gözle görülen ürünlerdir. Soyut olan hizmetler ise; muayene, ameliyat, checkup, rehabilitasyon, fizik tedavi, laboratuvar ve röntgen hizmetleri gibi ürünlerdir. Tengilimoğlu'na göre sağlık kurumlarındaki genişletilmiş hizmetler ise; tıbbi olmayan dolaylı hasta bakımı, teknik hizmetler, idari hizmetler, otelcilik hizmetleri, yemek, ambulans hizmetleri, otopark, danışma ofisleri ve mali işler gibi hizmetlerdir (Tengilimoğlu, 2016) 
Fiyat Stratejileri: Konu sağlık olunca kullanıcıların fiyat bileşenini önemsemedikleri ve sağlıklarına kavuşmak için gereken bedeli ödemeye hazır oldukları bilinmektedir. Ama sağlık hizmeti sunan kurumların sayısının çok olması ve kullanıcıların alternatiflerinin çoğalması, onlara en iyi sağlık hizmetini en uygun fiyata alma imkanını sunar.

Fiyat işletmelerin kârlılığını sürdürebilmesi, sermaye yatırımlarını yapabilmesi ve hedeflerini gerçekleştirebilmesi için en çok kullanılan pazarlama elemanıdır. "Fiyat işletmenin ürettiği mal ve hizmetler için belirlediği ve tüketicinin ödeyebileceği değeri ifade eder.” Bu yüzden işletmeler fiyatlandırma stratejilerinden yararlanarak kendilerine en uygun fiyatlandırma yöntemlerini seçerler. Sağlık kurumları da kendilerine en uygun fiyatlandırma stratejilerini belirlerken kendi karlılığının yanında hastaların çıkarlarını da korumak zorundadırlar.

Tutundurma ve Tanıtım Çalışmaları: Tutundurma karması bileşenleri, reklam, kişisel satış, halkla ilişkiler ve satış geliştirme şeklinde dört gruptan oluşur. Kotler (2000) buna halkla ilişkiler, etkinlik ve tecrübeler ve doğrudan pazarlamayı da eklemişleridir. Türkiye'de ve dünyada pek çok ülkede sağlık hizmetleri veren kuruluşlara doğrudan reklam yasağı getirilmiş, diğer tanıtım faaliyetleri de sınırlarla belirlenmiştir. Bu yüzden sağlık kuruluşları doğrudan reklam ve tanıtım yerine, dolaylı yoldan tanıtım ve halkla ilişkiler çalışmalarına yoğunlaşmayı tercih etmişlerdir. Hastanelerin web siteleri, facebook, instagram, twitter gibi sosyal medya araçları, sponsorluklar, kampanyalar sağlık hizmetlerinde tanıtım çalışmalarına örnek verilebilir. Ayrıca iyi bir veri tabanı oluşturularak hedef kitleye sms, e mail ve telefon yolu ile de tanıtım yapılabilir.

Yer/Dağıtım: Sağlık kurumlarında hizmetin sunumu üç şekilde olur. Hasta kuruma kendisi gelebilir, evde bakım için kurum eve hizmet götürebilir, telefon veya internet aracılığı ile hasta hizmet alabilir veya web sayfasından istediği bilgilere ulaşabilir. Hastanenin mobil uygulaması sayesinde pek çok işlemi uzaktan yapabilir. Bir sağlık kurumunda hastaların sağlık hizmetine ulaşma kolaylığı, istediği saatte randevu bulabilme ve muayene olma seçeneğinin olması, uzun bekleme sürelerinin olmaması, uzaktan da olsa bilgiye ulaşabilmesi; çevrimiçi ve web hizmetlerinin kalitesi yani zaman ve yer kullanımından fayda sağlaması kurumun dağıtım işlevini doğru olarak yerine getirdiğini gösterir.

Fiziksel Koşullar: Mal üretmeye yoğunlaşmış işletmelerden çok hizmet sektöründekilerini ilgilendiren fiziksel kanıtlar bileşeni, hizmetin sunulduğu bina için 
1şıklandırma, 1sıtma, renklendirme, ses, müzik ve koku gibi unsurları içerir. Örneğin hastanelerde bekleme salonlarında koltukların dizilme şekli, duvarlarda moral bozucu afişlerin olmaması, hastanenin mutfağından kötü yemek kokularının gelmemesi, dekorasyonun huzur ve mutluluk vermesi, hasta memnuniyetini artıran çok önemli faktörlerdir. Hastane odalarındaki yatakların rahatllğı ve temizliği, muayene odalarında mahremiyete dikkat edilmesi, cihaz, araç ve gereçlerin son teknoloji ürünü olması, koltuklarda söküklerin, tuvaletlerde damlayan muslukların olmaması, ortamın havasız kalmaması, binanın temizlik ve ferahlığı hastaların moralini olumlu yönde etkileyen özelliklerdir.

İnsan/Çalışanlar: Tüm hizmet sektörlerinde olduğu gibi, sağlik sektöründe de personel ile müşteri (hasta) teması en üst seviyededir. Palmer sağlık kurumlarında çalışan personelin tümünün (güvenlik görevlisi, otopark görevlisi, danışma görevlileri, laborantlar, hizmetliler, hemşireler, hasta bakıcılar, temizlik görevlileri, müdürler, üst düzey yöneticiler, doktorlar) yarı zamanlı pazarlamacılar olduğunu ileri sürer (Palmer,2014). Sağlık hizmetlerinde çok farklı kademelerde ve alanlarda pek çok insan görev almaktadır. Doktorlar, hemşireler, sağlık teknisyenleri, laboratuar görevlileri, fizyoterapistler, diş hekimleri, psikologlar, tıbbi sekreterler, güvenlik, otopark, temizlik, danışma görevlileri, otelcilik ve yemek hizmetlerinde çalı̧̧anlar, memurlar (idari personel) ve yöneticiler sağlık hizmetlerinde çalışan personelin bazılarıdır.

Süreçler: Hastanelerde iş süreçleri, hastaların randevu alarak hastaneye gelişi ve hasta kaydıyla başlar, çıkış ve ödeme işlemleri ile sona erer. Bu iki aşamanın arasında pek çok süreç yerine getirilir. Doktor seçimi ve branş belirleme, muayene için sıra bekleme, muayene işlemleri, bilgilerin otomasyon sistemine aktarılması, tetkiklerin yapılması (laboratuar, röntgen, MR, vb.), sonuçların alınması ve tekrar değerlendirilmesi, tedavi şekline karar verilmesi, yatış veya ayakta tedavi işlemleri, cerrahi işlemler, yoğun bakım ve acil servis hizmetleri en yoğun kullanılan hastane süreçleri arasındadır.

Sağlık kurumlarının çok fazla hastaya hizmet vermesi ve sağlık personeli sayısının kısıtlı olması yüzünden bazen bekleme süreleri uzun olmakta ve zaten sağlık durumu kötü olan hastaların moralinin bozulmasına sebep olmaktadır. Sağlık kurumlarına düşen bu süreçlerin en kısa ve kolay şekilde geçmesini sağlamak için çaba göstermektir.

\section{Yöntem}


Çalışma tanımlayıcı olup sağlık hizmetlerinde pazarlama faaliyetlerini inceleyen çalışmaların derlenmesinden oluşmaktadır. Aşağıda çalışmaya dâhil edilen makaleler ile ilgili bilgiler verilmiştir.

\subsection{Araştırmaya Dâhil Edilen Çalışmaların Seçilme Ölçütü}

Çalışma kapsamına alınacak makalelerin seçiminde yayın dilinin Türkçe veya İngilizce olması, 2000-2017 yılları arasında düzenlenmesi ve sağlı hizmeti kullanıcılarının tercihlerini araştıran çalışmalar olması ölçüt olarak belirlenmiştir. Amaca yönelik verilerin toplanmasında Dicle Üniversitesi Kütüphanesi veri tabanı taranmıştır. Tarama yapılırken "sağlık, kullanıcı, hasta, tüketici, memnuniyet, pazarlama, pazarlama bileşeni” anahtar kelimeleri kullanılırken, yabanc1 kaynaklı veritabanları taranırken, "health, healthmarketing, patient, consumer, satisfaction, marketing mix elements" anahtar kelimeleri kullanılmıştır.

Kullanılan veri tabanları ve anahtar kelimelerin seçilmesinde konu ile ilgili bütün çalışmalara ulaşmak hedeflenmiştir. Elektronik arama ile saptanan ilgili tüm makalelerin başlık ve özetleri, araştırmacılar tarafından bağımsız olarak gözden geçirilmiştir. Eğer başlık ya da özet açık değilse, çalışmanın dahil olma kriterlerine uyup uymadığının araştırılması için çalışmanın tam metni incelenmiştir. Araştırmacılar tarafından veri tabanlarından ilgili olan 102 makale incelenmiştir. İnceleme ölçütlerine uyan 30 makale incelemeye alınmış, geri kalan makaleler tam metine ulaşamama ve yeterli bilgi içermeme sebeplerinden inceleme dişında bırakılmıştır. Araştırmacıların incelemeleri daha sonra karşılaştırılmış ve uygun olan çalışmaların tam metinleri alınmıştır. Verilerin özetlenmesi için standart bir veri özetleme formu geliştirilmiş ve veriler buna göre değerlendirilmiştir. Araştırmaya dahil edilen çalışmalar karşılaştırılmış ve tüm çalışmaları içerecek bir veri özetleme formu oluşturulmuştur. Veri özetleme formunda, çalışmayı gerçekleştiren yazarın ismi ve çalışmanın yapıldı̆̆ı yıl, yer ve örneklemi ile bulguları özetlenerek tablo halinde sunulmuştur.

\section{Bulgular}

Bu literatür inceleme çalışmasında, 2000-2017 yılları arasında yayınlanan 30 çalışma yer almaktadır. Sağlık hizmetlerinde kullanıcı tercihlerinde pazarlama bileşenlerinin etkisini araştıran çalışmaların sonuçları Tablo 1'de verilmiştir. Bu tabloda seçilen 30 makale; yazarları, araştırmanın yayınlandığı yıl, yapıldığı ülke, örneklemi, kullanılan yöntem ve araştırmadan elde edilen önemli bulgular yer almaktadır. 


\section{Tablo 1}

Sağlık hizmetlerinde pazarlama faaliyetleri üzerine yapılan araştırmalar.

\begin{tabular}{|c|c|c|c|c|}
\hline Yazar Adı & $\begin{array}{c}\text { Yayın } \\
\text { yılı }\end{array}$ & $\begin{array}{c}\text { Çalışmanın } \\
\text { yeri }\end{array}$ & Örneklem & Bulgular \\
\hline $\begin{array}{l}\text { 1.Gümüş \& } \\
\text { Sönmez }\end{array}$ & 2018 & İstanbul & 442 & $\begin{array}{l}\text { İstanbul'da kullanıcılar tarafindan en çok kullanıldığı } \\
\text { belirlenen } 100 \text { hastane web sayfası yedi boyutta } \\
\text { incelenmiş, } 45^{\prime} \text { 'inin iyi, } 35 \text { 'inin orta, } 25 \text { 'inin ise } \\
\text { mükemmel düzeyde olduğu belirlenmiştir. } \\
\text { Kullanıcıların tercih ettikleri hastanelerin web sayfası } \\
\text { skorları değerlendirmede yüksek çıkmıştır. Web } \\
\text { sayfası kaliteli olan hastanelerin tercih edilme oranı } \\
\text { yüksektir. }\end{array}$ \\
\hline $\begin{array}{l}\text { 2.Erdugan } \\
\text { vd. }\end{array}$ & 2017 & Türkiye & 1349 & $\begin{array}{l}\text { Doktorlar ve fiziksel koşullar açısından en fazla } \\
\text { memnuniyet kadın doğum polikliniğindedir. Uzun } \\
\text { bekleme süreleri hastaların tekrar satın alma niyetini } \\
\text { olumsuz etkilemektedir. }\end{array}$ \\
\hline 3.Kumah & 2017 & İtalya & 151296 & $\begin{array}{l}\text { Katılımcılar sağlık kurumlarını tercih etmedeki en } \\
\text { önemli etkenlerin sağlık personelinin ilgisi, } \\
\text { hemşirelerin sorumluluk sahibi olması, doktorlarla } \\
\text { iletişim ve ortamın huzur u olarak belirtmişlerdir. }\end{array}$ \\
\hline $\begin{array}{l}\text { 4.T.C.Sağlık } \\
\text { Bakanlığı }\end{array}$ & 2017 & Türkiye & 8360 & $\begin{array}{l}\text { Kurumun eve yakınlığı, hastaneye duyulan güven, } \\
\text { hasta hakkına saygı ve teknolojik olanaklar en önemli } \\
\text { etkenlerdir. Sağlık hizmetlerinden genel memnuniyet } \\
\text { oranı \%76 olarak belirlenmiş, en yüksek oran Batı } \\
\text { Karadeniz, en düşüğü ise Batı Marmara bölgesinde } \\
\text { görülmüştür. Aile Sağlığı Merkezleri ve Aile } \\
\text { Hekimliği en çok gidilen sağlık kurumları olurken, } \\
\text { ikinci sırada devlet hastaneleri, üçüncü sırada ise } \\
\text { üniversite hastaneleri gelmektedir. }\end{array}$ \\
\hline
\end{tabular}




\begin{tabular}{|c|c|c|c|c|}
\hline \multirow{2}{*}{$\begin{array}{l}\text { 5.Tüfekçi ve } \\
\text { vd. }\end{array}$} & \multirow[t]{2}{*}{2016} & \multirow[t]{2}{*}{ Isparta } & \multirow[t]{2}{*}{336} & $\begin{array}{l}\text { Doktorların tanınmışlı̆̆ı, hastanenin temiz ve hijyenik } \\
\text { olması, ileri teknolojik cihazların kullanımı, hizmet } \\
\text { kalitesi, kurumun tanınmışlı̆ı/imajı ve hastanenin } \\
\text { güvenirliği ilk sıralarda gelmiştir. }\end{array}$ \\
\hline & & & & $\begin{array}{l}\text { En son sıralarda reklam ve tanıtım, hastanenin iç } \\
\text { dizaynı, kullanılan renkler, logo ve binanın tasarımı } \\
\text { gelmiştir. }\end{array}$ \\
\hline 6.Işs1k & 2016 & Sakarya & 610 & $\begin{array}{l}\text { İnanç ve etnik kökene saygı, şikayetlerin dikkate } \\
\text { alınması, hastalara gösterilen ilgi, personele duyulan } \\
\text { güven hastanenin marka imajına ve marka güvenine } \\
\text { olumlu etki yapmaktadır. }\end{array}$ \\
\hline 7.Şantaş vd. & 2016 & Giresun & 283 & $\begin{array}{l}\text { Temizlik ve hijyen, doktorların tutumu, teknolojik } \\
\text { olanaklar, personelin davranışı tercih sebeplerinin } \\
\text { başında gelmektedir. } \\
\text { Hasta grubunda yaşı genç olanlar, kadınlar, eğitimli } \\
\text { olanlar ve yüksek gelirliler hizmete diğerlerinden daha } \\
\text { çok önem vermektedirler. Hastanenin imajına ve } \\
\text { tanınmışlığına kadınlar daha fazla önem vermektedirler }\end{array}$ \\
\hline 8.Sunal & 2016 & Ankara & 300 & $\begin{array}{l}\text { Hastaneye ulaşım kolaylığı, randevu saatlerine uyma, } \\
\text { kurumun aldığı ödüller, hastanenin fiziksel koşulları } \\
\text { kullanıcı tercihlerinde ilk sebeplerdir. } \\
\text { Araştırmanın sonuçlarına göre, bireylerin eğitim } \\
\text { seviyeleri arttıkça doktorların uzmanlığına daha fazla } \\
\text { önem verilmekte ve sosyal medyadaki reklam ve } \\
\text { tanıtımlardan daha fazla etkilenilmektedir. }\end{array}$ \\
\hline 9.Öncü vd. & 2016 & Türkiye & $\begin{array}{l}390 \text { Yerli } \\
\text { ve yabanc1 } \\
\text { hasta }\end{array}$ & $\begin{array}{l}\text { Katılımcılar için memnuniyet ile tekrar satın alma ve } \\
\text { marka bağlılığı arasında güçlü bir ilişki bulunmuştur. } \\
\text { Yabancı hastalar hizmet konusunda yerli hastalar ile } \\
\text { eşit muamele gördüğünü düşünürken yerli hastalar } \\
\text { bunun tersini düşünmektedir. }\end{array}$ \\
\hline
\end{tabular}




\begin{tabular}{|c|c|c|c|c|}
\hline 10.Nitin vd. & 2016 & Hindistan & 200 & $\begin{array}{l}\text { Yardım masası olanăğ, doktor ve hemşirelerin tutumu, } \\
\text { tanıtım ve reklam faaliyetleri, tıbbi hizmetlerin kalitesi } \\
\text { en fazla etkili olan faktörlerdir. Tıbbi hizmetlerin yanı } \\
\text { sıra pazarlama bileşenlerinden faydalanmanın } \\
\text { hastanelerin doluluk oranlarını arttırmaları için şart } \\
\text { olduğu ortaya koyulmuştur. }\end{array}$ \\
\hline 11.Park vd. & 2016 & Kore & 1573 & $\begin{array}{l}\text { Bir sağlık kurumunda hasta tercihini belirleyen en } \\
\text { önemli unsurlar tedavinin kalitesi, fiyatların uygunluğu } \\
\text { ve sağlı kurumunun ulaşılabilirliği olarak } \\
\text { bulunmuştur. }\end{array}$ \\
\hline 12.Gümüş & 2016 & Diyarbakır & 200 & $\begin{array}{l}\text { Hastane web sitelerini kullanım açısından görev birimi, } \\
\text { yaş ve eğitim açısından fark bulunamamıştır. Sağlı } \\
\text { hizmeti kullanıcılarının hastane web sayfalarından en } \\
\text { büyük beklentileri randevu ve sonuç alma, web } \\
\text { sitesinin hızı, bilgilere erişim kolaylığı ve doktor } \\
\text { bilgileridir. }\end{array}$ \\
\hline 13.Kıray & 2015 & Pamukkale & 1071 & $\begin{array}{l}\text { Bir sağlık kurumunda en fazla önem verilen faktörler } \\
\text { doktor ve hemşirelerin davranışı, hastanenin temizliği, } \\
\text { hastanenin ortamı ve ferahlığı olarak bulunmuştur. }\end{array}$ \\
\hline $\begin{array}{l}\text { 14.Edinsel } \\
\text { \& Adıgüzel }\end{array}$ & 2014 & Türkiye & $\begin{array}{l}524 \text { sağlık } \\
\text { turizmi } \\
\text { kullanıcısı }\end{array}$ & $\begin{array}{l}\text { Özel sağlık kuruluşu olması, göz, diş ve saç ekimi } \\
\text { uzmanlaşması, hastanenin teknolojik yönden donanımlı } \\
\text { olması yabancı hastaların en önem verdiği konulardır. } \\
\text { Türkiye'ye sağlık turizmi amacıyla gelen turistlerin } \\
\text { çoğunun Almanya, Libya, Rusya, Irak, Hollanda, } \\
\text { Azerbaycan ve İngiltere vatandaşı olduğu bulunmuştur. } \\
\text { En fazla başvurulan tedavi hizmetlerinin ise göz } \\
\text { ameliyatları, saç ektirme, checkup, diş tedavileri, } \\
\text { ortopedi ameliyatları, kbb sorunları ve diyaliz } \\
\text { hizmetleri olduğu bildirilmiştir. }\end{array}$ \\
\hline
\end{tabular}




\begin{tabular}{|c|c|c|c|c|}
\hline 15.Öz vd. & 2014 & Karaman & 326 & $\begin{array}{l}\text { Çevrenin tavsiyesi, doktor ve hemşirelerin yeterliliği, } \\
\text { sağlık personelinin güvenilirliği en önemli faktörlerdir. } \\
\text { Katılımcıların çoğunluğu verilen sağlık hizmetlerinden } \\
\text { memnun olurlarsa yine aynı sağlı kuruluşuna } \\
\text { başvuracaklarını, başkalarına da tavsiye edeceklerini, } \\
\text { sosyal medyadan duyuracaklarını ve hastaneye olumlu } \\
\text { geri bildirim yapacaklarını belirtmişlerdir. }\end{array}$ \\
\hline $\begin{array}{l}\text { 16.Karaçor } \\
\text { \& Arkan }\end{array}$ & 2014 & Konya & 160 & $\begin{array}{l}\text { Personelin davranışı, sağlık personelinin bilgi düzeyi, } \\
\text { kurumda sunulan hizmetler, fiziksel ortamın rahatlığı } \\
\text { ve süreçlerin kolaylığı en önemli bulunan etkenlerdir. } \\
\text { Yaşlı hastalar için sunulan hizmetler önem taşırken, } \\
\text { gençler fiziksel ortama daha fazla önem } \\
\text { vermektedirler. Eğitimi ve gelir düzeyi düşük olanların } \\
\text { reklamlardan daha fazla etkilendiği belirlenmiştir. }\end{array}$ \\
\hline 17. Barın vd. & 2014 & Türkiye & $\begin{array}{c}214 \\
\text { Engelli } \\
\text { hasta }\end{array}$ & $\begin{array}{l}\text { Genel olarak engelli hastalar hastanedeki fiziksel } \\
\text { olanaklardan ve hekimlerin davranışlarından } \\
\text { memnundur. Sağlik personelinin yeterince yardımcı } \\
\text { olduğunu ve hastanedeki işaretlerin ve } \\
\text { yönlendirmelerin yeterli olduğunu düşünmektedirler. }\end{array}$ \\
\hline 18.Şahin & 2013 & Malatya & 167 & $\begin{array}{l}\text { Randevu sisteminin düzgünlüğü, personelin gösterdiği } \\
\text { ilgi tercih sebepleridir. Doktorlar tarafından } \\
\text { bakıldığında ise, doktorlar randevulu gelen hastalardan } \\
\text { çok şikayetçi etmiş ve onları sabırsız ve saygısız } \\
\text { olarak nitelendirmişlerdir. }\end{array}$ \\
\hline $\begin{array}{l}\text { 19.Zerenler } \\
\text { \& Öğüt. }\end{array}$ & 2013 & Konya & 374 & $\begin{array}{l}\text { Kurumun sosyal güvenlik anlaşması olması, çevrenin } \\
\text { tavsiyesi, doktorların tanınmışlığı, fiziksel unsurlar, } \\
\text { kuruma ulaşımın kolaylığı ilk sıralarda gelirken, } \\
\text { bekleme süreleri, kayıt işlemlerinin kolay ve hızlı } \\
\text { olması gibi süreçler en son sırada gelmiştir. }\end{array}$ \\
\hline
\end{tabular}




\begin{tabular}{|c|c|c|c|c|}
\hline $\begin{array}{l}\text { 20.Purcarea } \\
\text { vd. }\end{array}$ & 2013 & Romanya & 183 & $\begin{array}{l}\text { Çevrenin tavsiyesi, internetten edinilen bilgi, tedavi ve } \\
\text { hizmetlerin kalitesi en önemli etkenlerdir. Kalite algısı } \\
\text { sıralamasında güvenirlik, bağlılık ve empati yüksek } \\
\text { bulunurken, fiziksel koşullardan memnuniyet düşük } \\
\text { çıkmıştır. }\end{array}$ \\
\hline 21.Yılmaz & 2014 & İstanbul & 342 & $\begin{array}{l}\text { Bir sağlık kuruluşu ya da hekim hakkında arkadaş, } \\
\text { akraba veya başkalarının verdikleri tavsiyeler, sağlık } \\
\text { hizmeti kullanıcıları üzerinde tüm tanıtım } \\
\text { faaliyetlerinden daha büyük etkiye sahiptir. Hastaların } \\
\text { en fazla tavsiye aldıkları kişiler aile ve akrabalar olup, } \\
\text { bunu arkadaşlar ve yakınlar izlemektedir. İnternetteki } \\
\text { yorumlar da üçüncü sıradadır. }\end{array}$ \\
\hline $\begin{array}{l}\text { 22.Tarım \& } \\
\text { Zaim }\end{array}$ & 2010 & İstanbul & 800 & $\begin{array}{l}\text { Katılımcılar için en önemli etkenler muayene } \\
\text { odalarının konforu, doktorların görünüşü, hastaya } \\
\text { ayırılan vakit ve ilgi, hastanenin ortamının ferahlığıdır. }\end{array}$ \\
\hline $\begin{array}{l}\text { 23.Demirel } \\
\text { vd. }\end{array}$ & 2009 & Aksaray & 124 & $\begin{array}{l}\text { Kurumun modern ve bakımlı olması, çevrenin } \\
\text { tavsiyesi, doktorların bilgisi ve hizmet kalitesi tercih } \\
\text { sebeplerinde en önemli etkenlerdir. } \\
\text { Katılımcıların çoğu tekrar geleceğini ve başkalarına da } \\
\text { tavsiye edeceğini belirtmiştir. Algılanan hizmet kalitesi } \\
\text { ile hastaneyi tekrar tercih etme ve başkalarına tavsiye } \\
\text { etme arasında pozitif bir ilişki belirlenmiştir. Özellikle } \\
\text { hemşirelik hizmetleri ve kuruma duyulan güven ile } \\
\text { tavsiye etme ve tekrar tercih etme arasında güçlü bir } \\
\text { ilişki bulunmuştur. }\end{array}$ \\
\hline $\begin{array}{l}\text { 24.Torres } \\
\text { vd. }\end{array}$ & 2009 & Şili & 250 & $\begin{array}{l}\text { Hastaların çoğu en çok etkilendikleri faktörün } \\
\text { doktorların hastaya davranışı ve hastanenin fiziksel } \\
\text { koşulları olduğunu belirtmiş̧ir. }\end{array}$ \\
\hline
\end{tabular}




\begin{tabular}{|c|c|c|c|c|}
\hline 25.Kim vd. & 2008 & $\begin{array}{l}\text { Güney } \\
\text { Kore }\end{array}$ & 498 & $\begin{array}{l}\text { Hastanenin tanınırlığı, kurumun güvenilirliği, } \\
\text { hastaneye duyulan güven ve hasta memnuniyeti marka } \\
\text { bağlllığı ve marka farkındalığı üzerinde pozitif bir } \\
\text { etkiye sahiptir. Hastaların sağlık kurumlarını evlerine } \\
\text { yakınlığına göre seçtiği de başka bir bulgudur. Marka } \\
\text { güveni ve hasta memnuniyetinin hastane imajı üzerinde } \\
\text { pozitif bir etkisi olduğu ortaya konulmuştur }\end{array}$ \\
\hline 26.Özaktan & 2008 & Ankara & 304 & $\begin{array}{l}\text { Kurumun güvenilirliği, hastanenin imajı, hastanenin } \\
\text { fiziksel koşulları en önemli etkenlerdir. Genç yaştaki } \\
\text { hastaların beklentileri daha az karşılanırken, eğitim } \\
\text { seviyesinin yükselmesi de memnuniyeti azaltmaktadır. } \\
\text { Aylık geliri fazla olanların da memnuniyet düzeyi daha } \\
\text { düşük bulunmuştur. }\end{array}$ \\
\hline 27.Şule & 2008 & Ankara & 307 & $\begin{array}{l}\text { Hekimlerin tanınırlığı, kurumun marka imajı, ve } \\
\text { fiziksel özellikler en önemli bulunan etkenlerdir. } \\
\text { Eğitim düzeyi yüksek olanlar ve genç yaştakiler } \\
\text { markası daha fazla bilinen hastaneleri tercih } \\
\text { etmektedir. Hastane seçiminde birinci sırada } \\
\text { hekimlerin tanınırlığı gelirken, logo ve isim yazılışı en } \\
\text { son sırada gelen sebeplerdir. Gençler çalışanların } \\
\text { görüntüsünü çok önemli bulurken kadınlar da } \\
\text { hastanenin dekorasyonunda kullanılan renklere ve iç } \\
\text { dizayna çok önem verdiğini ifade etmiştir. Hastane } \\
\text { hakkında çıkan olumsuz haberlere eğitim seviyesi } \\
\text { yüksek olanlar itibar etmediklerini belirtmişlerdir }\end{array}$ \\
\hline 28.Demir & 2008 & Kocaeli & 120 & $\begin{array}{l}\text { Doktorların bilgi ve tecrübesi, mahremiyete saygı, } \\
\text { fiyatların makullüğü, kayıt ve taburculuk işlemlerinin } \\
\text { kolaylığı hastalar için ilk sıralarda gelmektedir. Gelir } \\
\text { düzeyi ve eğitim düzeyi düşük olanlar ve yaşı büyük } \\
\text { katılımcılar hizmet kalitesini daha yüksek seviyede } \\
\text { algılamaktadırlar }\end{array}$ \\
\hline
\end{tabular}




\begin{tabular}{|c|c|c|c|c|}
\hline 29.Choi vd. & 2005 & $\begin{array}{l}\text { Güney } \\
\text { Kore }\end{array}$ & 557 & $\begin{array}{l}\text { Hastane seçiminde en önemli etkenler İnanç ve etnik } \\
\text { kökene saygı duyulması, şikâyetlerin dikkate alınması, } \\
\text { hastalarla ilgilenilmesi ve hemşire ve diğer personelin } \\
\text { davranışlarıdır. Yaşlı hastaların hastaneden } \\
\text { memnuniyeti daha yüksek bulunmuştur. Doktorlar } \\
\text { dışındaki sağlık personelinden memnuniyet daha } \\
\text { yüksek çıkmıştır. }\end{array}$ \\
\hline 30.Fung vd. & 2005 & U.S.A & 304 & $\begin{array}{l}\text { Doktorun bilgisi, doktorun ilgili davranması ve sağlık } \\
\text { personelinin davranışı en önemli tercih sebepleridir. }\end{array}$ \\
\hline
\end{tabular}

Araştırmanın bulgularına göre sağlık hizmeti kullanıcıları sağlık kurumu seçerken tüm pazarlama bileşenlerine (ürün, insan, fiyat, tanıtım, süreç, fiziksel koşullar, yer) aynı oranda önem vermemektedirler. Pazarlama bileşenlerinden insan boyutu en önem verilen bileşendir. Sağlık kurumuna başvuran hastalar herhangi bir müşteri gibi değildir. Hastalar, kırılganlığı ve güvensizliği en yüksek seviyede olan, yanlış anlamaya elverişli, özel ilgi ve anlayış isteyen müşteri grubundandır. Sağlık kurumlarındaki Doktorlar, hemşireler, sağlık teknisyenleri, laboratuvar görevlileri, fizyoterapistler, diş hekimleri, psikologlar, tıbbi sekreterler, güvenlik, otopark, temizlik, danışma görevlileri, otelcilik ve yemek hizmetlerinde çalışanlar, memurlar (idari personel) hasta kuruma girdikten çıkana kadar onunla birebir iletişim halinde olan kişilerdir. Bu yüzden bu kişilerin hastaya gösterdiği güler yüz, ilgi ve anlayış sağlık kurumlarını seçmede en üstte gelen kriterdir. Araştırma kapsamına alınan çalışmalardan 19'unda (2, 3, 5, 6, 7, $9,10,13,15,16,18,19,22,23,24,27,28,29,30)$ sağlık kurumlarında pazarlama bileşenlerinden insan boyutu en fazla önem verilen unsurdur.

Sağlık hizmeti kullanıcıları için en önemli ikinci pazarlama bileşeni hastanenin fiziksel koşullarıdır. Sağlık hizmetinin sunulduğu bina için ışıklandırma, 1sıtma, renklendirme, ses, müzik ve koku gibi unsurlar, dekorasyonun huzur ve mutluluk vermesi, hasta memnuniyetini artıran çok önemli faktörlerdir. Hastane odalarındaki yatakların rahatlığı ve temizliği, muayene odalarında mahremiyete dikkat edilmesi, cihaz, araç ve gereçlerin son teknoloji ürünü olması, koltuklarda söküklerin, tuvaletlerde damlayan muslukların olmaması, ortamın havasız kalmaması, binanın temizlik ve ferahlığı hastaların moralini olumlu yönde etkileyen özelliklerdir. Araştırma kapsamındaki 14 çalışmada $(2,3,5,7,8,13,14,16,17,19,22,23,24,27)$ sağlık hizmeti kullanıcılarının kurumun fiziksel özelliklerine en üst sırada önem verdiklerini ortaya koymuştur. 
Sağlık kurumlarının reklam ve tanıtım olanaklarının hepsinden yararlandıkları ama en önemli tanıtımın hasta memnuniyeti ile tavsiye olduğu bilinmektedir. Hastanelerin web siteleri, facebook, instagram, twitter gibi sosyal medya araçları, sponsorluklar, kampanyalar, sms, e-mail ve telefon ile iletişim hastalar üzerinde olumlu etki yapan unsurlardır. Sağlık hizmeti kullanıcılarının tercih sebeplerine bakıldığında araştırmaların 13'ünde $(1,5,8,10,12,15,19,20$, $21,23,25,26,27)$ sağlık kurumlarının marka değeri, imajı, tavsiye edilme durumu ve tanıtım çalışmaları önemli sebepler arasında gelmiştir.

Sağlık kurumlarında en önem verilen unsurlardan bir diğeri hastanede sunulan ürün ve hizmetlerin kalitesidir. Tıbbi araç ve gereçler, tıbbi cihazlar, laboratuvar malzemeleri, ilaçlar, tedavi malzemeleri, protezler, muayene, ameliyat, checkup, rehabilitasyon, fizik tedavi, laboratuvar ve röntgen hizmetleri ile dolaylı hasta bakımı, teknik hizmetler, idari hizmetler, otelcilik hizmetleri, yemek, ambulans hizmetleri, otopark, danışma ofisleri ve mali işlerin kalitesi hastalar için sağlık kurumunu seçmede en önemli etkenlerdendir. Araştırma kapsamındaki 8 yayında $(4,5,10,11,14,16,19,23)$ ürün ve hizmetler en çok önem verilen hususlar olarak öne çıkmıştır.

Araştırmada geçmişteki makalelerde en az önemli bulunan faktörler, yer/dağıtım $(4,8,11$, $19,25)$, süreç $(8,16,18,28)$ ve fiyat $(11,19,28)$ değişkenidir. Sağlığın tüm bireyler için en önemli değer olduğu göz önüne alındığında fiyatının yani maliyetinin önemsenmeyeceği açıtır. Her birey kendi bütçesine göre en iyi hizmeti en uygun koşulda almaya çalışacaktır. Hastanelerin uzaklığ̣ da çok önem arz eden konulardan biri değildir. Gerek hastane sayısının artması, gerekse ulaşımdaki kolaylıklar kullanıcılara sağlık hizmeti almak için istediği hastaneye gidebilme imkânı sağlamaktadır. Süreç değişkeni ise çoğu zaman ürün ve hizmetler gibi algılandığından süreci başka bir pazarlama bileşeni olarak ayırmak güçtür.

\section{Sonuçlar}

Araştırmanın bulgularına göre, sağlık hizmetleri veren kurumların pazarlama bileşenlerinden faydalanmasının kullanıcı sayısındaki artışa sebep olacağı söylenebilir. Tüm sektörlerde olduğu gibi sağlık kurumları da reklam ve tanıtım olanaklarından faydalanırken bunun yanında kendi fiziksel koşullarına ve personelinin davranış ve tutumlarına çok önem vermelidirler. Gerek zaman zaman yapılan kurum içi ve dışı eğitimlerle gerek belirli aralıklarla 
yapılan anketlerle personelinin iş memnuniyetini yükseltmeli, çalışma koşullarını iyileştirmelidir. Mutlu çalışan mutlu müşteri demektir.

Rekabetin en üst düzeyde sürdüğü sağlık hizmetlerinde neredeyse tüm hastaneler tam donanımlı teknolojik ve konforlu hizmetler sunmakta, binalarını en yüksek kalitede donatmaktadırlar. Bu yüzden fiziksel koşullarının kalitesi düşük olan kurumların diğerleri ile rekabet etmesi olanaksızdır. Çalışmamızın bulgularından görülmüştür ki, yer ve fiyat değişkenini pek umursamayan sağlık hizmeti kullanıcıları konu sağlık olduğunda aradığı sağlık hizmetini nerede olursa ve kaça mal olursa olsun arayıp bulmayı göze almaktadır. Ağızdan ağza pazarlamanın en iyi reklam ve tanıtım aracı olduğu, dost ve aile tavsiyesinin ön plana çıktığı, hem iyi hem de kötü reklamların en kısa zamanda yayılıp, duyulduğu günümüzde sağlık kurumları imajına v güvenilirliğine çok dikkat etmelidir.

Teknolojinin sunduğu imkânlardan yararlanarak, web sayfalarını, sosyal medya hesaplarını interaktif olarak kullanan kurumundaki haberleri gelişmeler, aldığı ödüller gibi bilgileri paylaşan, hastalarının dilek, şikâyet ve önerilerini dikkate alan, halkla ilişkiler çalışmalarını sıkı tutan, basın ve diğer medya organları ile ilişki içinde olan sağlık kurumları yakın gelecekte en fazla tercih edilen işletmeler olacaktır.

Sağlık hizmetlerinde rekabetin yüksek olması kurumların kalitesini yükseltmesini ve bunun da hastaların lehine bir durum olduğu açıktır. Hastalar pek çok seçenek içinde kendilerine en uygun sağlık kurumunu ararken beklentilerini en fazla karşılayan hastanelere yönelecektir. Hasta sayısını artıran bu kurumlar içinde olumlu bir gelişme yaşanırken çift taraflı bir kazanç sağlanacaktır. Özellikle sağlık turizminin de çok ilerleme kaydettiği ülkemizde hem yerli hem yabancı kullanıcıların dikkatini çekmek isteyen sağlık kurumları için çalışmanın bir rehber olacağı düşünülmektedir. 


\section{Kaynakça}

Barın, İ., Doğru, K., Borlu, M., Özyurt, Ö., Kayabaşı, A. \& Yenisu M. (2014). İşlevsel düzenlemelerin, engelli hasta memnuniyetine olan yansıması Erciyes Tıp örneği. Sağlık Akademisyenleri Dergisi, 1(2), 128-135.

Booms, B. H. \& Bitner, M. J. (1981). Marketing Strategies and Organization Structures for Service Firms. In Donnelly, J. \& George, W. R. (Eds.), Marketing of Services (pp. 47 51). Chicago: American Marketing Association.

Borden, N. H. (1964). The concept of the marketing mix. Journal of Advertising Research, June(2), 2-7.

Choi, K., Hanjoon, L., Chankon, K. \& Sunhee, L. (2005). The service quality dimensions and patient satisfaction relationships in South Korea: comparisons across gender, age and types of service. Journal of Services Marketing, 19(3), 140-149.

Demir, S. (2008). Hastane hizmet kalitesi algılarında farklılaşmaya yol açan sebeplerin incelenmesi (Yayınlanmamış Yüksek Lisans Tezi), Gebze Yüksek Teknoloji Enstitüsü.

Demirel, Y., Yoldaş, M. A. \& Divanoğlu, S. (2009). Algılanan hizmet kalitesinin tatmin, tavsiye davranış1 ve tercih üzerine etkisi. Akademik Bakış, (16), 1-14.

Edinsel, S. \& Adıgüzel, O. (2014). Türkiye'nin sağlık turizmi açısından son beş yıldaki Dünya ülkeleri içindeki konumu ve gelişmeleri. Çankırı Karatekin Üniversitesi, İktisadi ve İdari Bilimler Fakültesi Dergisi, 4(2), 167-190.

Erdugan, F., Yörübulut, S., Şahin, E., \& Önce, S. (2017). Kırıkkale Üniversitesi Tıp Fakültesi Hastanesinde hasta ve çalışan memnuniyeti. Mehmet Akif Ersoy Üniversitesi Sosyal Bilimler Enstitüsü Dergisi, 9(18), 165-177.

Fung, C. H., Elliott, M. N., Hays, R. D., Kahn, K. L., Kanouse, D. E., McGlynn, E. A., Spranca, M. D. \& Shekelle, P. G. (2005). Patients' preferences for technical versus interpersonal quality when selecting a primary care physician. Health Services Research, 40(4), 957977.

Gümüş, R. (2016). Hastane web sitelerinin e-hizmet kalitesinin kullanıcıların hastane tercihleri üzerindeki etkisinin incelenmesi. 10. Sağllk ve Hastane Idaresi Kongresi (pp. 497-498) Ankara, 1-3 Aralık 2016.

Gümüş, R. \& Sönmez, Y. (2018). Quality of online communication tools at hospitals and their effects on health service consumers' preferences. International Journal of Healthcare Management, 1-10. doi: 10.1080/20479700.2018.1470816.

Işık, O. (2016). Algılanan kalitenin hastane marka değerine etkisi. Hacettepe Să̆lık İdaresi Dergisi, 19(1), 54-72.

Karaçor, S. \& Arkan, A. (2014). Sağlık kuruluşlarında pazarlama, sağlık pazarlama karması unsurlarının hasta/müşteri açısından önemi üzerine bir araştırma. Selçuk Üniversitesi İletişim Dergisi, 8(2), 90-118.

Kıray, C. (2015). Pamukkale Üniversitesi Tıp Fakültesi Hastanesi Acil Servisine Başvuran Hastaların Memnuniyetini Etkileyen Faktörlerin İncelenmesi (Yayınlanmamış Uzmanlık Tezi), Pamukkale Universitesi. 
Kim, K. H., Kim, K. S., Kim, D. Y., Kim, J. H. \& Kang, S. H. (2008). Brand equity in hospital marketing. Journal of Business Research, 6(1), 75-82.

Kotler, P. (2000). Pazarlama Yönetimi: Milenyum Baskı. (çev.) N. Muallimoğlu. İstanbul: Beta Yayınları.

Kumah, E. (2017). Patient experience and satisfaction with a healthcare system, connecting the dots. International Journal of Healthcare Management, 1-7, doi: 10.1080/20479700.2017.1353776.

McCarthy, E. J. (1960). Basic Marketing, A Managerial Approach. Homewood III: R.D. Irwin.

Mucuk, İ. ( 2016). Pazarlama İlkeleri (20. Bask1). İstanbul: Türkmen Yayınevi.

Nitin R. V., Narendranath V. \& Devakumar G. (2016). An empirical study on marketing mix strategies on healthcare services in a tertiary care hospital, International Journal of Management and Applied Science, 2(10), 19-24.

Öncü, M. A., Çatı, K. \& Yalman, F. (2016). Medikal turizm kapsamında gelen yabancı hastalar ile yerli hastaların memnuniyet ve sadakatlerinin karşılaştırılması. Bartın Üniversitesi I.I.B.F. Dergisi, 7(14), 31-42.

Öz, M. \& Uyar, E. (2014). Sağlık hizmetleri pazarlamasında algılanan hizmet kalitesi ve müşteri memnuniyeti üzerinde ağızdan ağıza pazarlamanın etkisini belirlemeye yönelik bir araştırma. KMÜ Sosyal ve Ekonomik Araştırmalar Dergisi, 16(26), 123-132.

Özaktan, Y. (2008). Hastane Işsletmelerinde Hizmet Kalitesinin Ölçülmesi ve Bir Üniversite Hastanesi Örneği (Yayınlanmamış Yüksek Lisans Tezi). Gazi Üniversitesi.

Palmer, A. (2014). Principles of Services Marketing. London: Mc Graw Hill Education.

Park, K., Park, J. Kwon, Y. D., Kang, Y. \& Noh, J. W. (2016). Public satisfaction with the healthcare system performance in South Korea. Health Policy, 120(6), 621-629.

Purcărea, V. L., Iuliana, R. G. \& Consuela, M. P. (2013). The assessment of perceived service quality of public health care services in Romania using the SERVQUAL scale. Procedia Economics and Finance, 6, 573-585.

Sunal, İ. (2016). Bireylerin Hastane Seçiminde Hastanenin Tanınırlı̆̆ ve Kurumsal Marka İmajı Tercihleri Analizi (Yayınlanmamış Yüksek Lisans Tezi). Atılım Üniversitesi.

Şahin, Ş. (2013). Merkezi Hastane Randevu Sistemi Uygulamasının Etkinlik, Farkındalı̆̆ının, Hasta Bekleme Süresine ve Memnuniyetine Etkisinin Ă̆ız ve Diş Sağllğı Merkezinde Değerlendirilmesi (Yayınlanmamış Yüksek Lisans Tezi). Okan Üniversitesi.

Şantaş, F., Kurşun,A. \& Kar, A. (2016). Hastane tercihine etki eden faktörler, sağlik hizmetleri pazarlaması perspektifinden alan araştırması. Hacettepe Să̆lık Idaresi Dergisi, 19(1), 1733.

Şule, E. (2008). Săgllk Sektöründe Marka Yaratma ve Hastane Seçiminde Markanın Etkisi (Yayınlanmamış Yüksek Lisans Tezi). Gazi Üniversitesi.

T.C. Sağlık Bakanlığı Sağlık Araştırmaları Genel Müdürlüğü (2017). Türkiye’de Vatandaşların Sağlık Hizmetlerine Yönelik Beklenti ve Memnuniyeti Araştırması Sonuç Raporu. Alınan yer https//sbu.saglik.gov.tr/Ekutuphane/Yayin/552. 
Tarım, M. \& Zaim, H. (2010). Hasta memnuniyeti: Kamu hastaneleri üzerine bir alan araştırması. Sosyal Siyaset Konferanslarl, 59(2), 1-24.

Tengilimoğlu, D. (2016). Sağlık Hizmetleri Pazarlaması (4. Baskı). İstanbul: Siyasal Kitabevi.

Torres, E., Vasquez-Parraga, A. Z. \& Cristobal, B. (2009). The path of patient loyalty and the role of doctor reputation. Health Marketing Quarterly, 26(3), 183-197.

Tüfekçi, N., İnce, O. G. \& Tüfekçi, O. K. (2016). Isparta'daki özel hastanelerin marka stratejilerini belirleyen faktörlere yönelik bir araştırma. Süleyman Demirel Üniversitesi İktisadi Ve İdari Bilimler Fakültesi Dergisi, 21(1), 321-338.

Yılmaz, E. (2014). Sağlık hizmetlerinde ağızdan ağıza pazarlama. Marmara Sosyal Araştırmalar Dergisi, (1), 1-19.

Zeithaml, V. A., Parasuraman, A. \& Malhotra, A. (2000). E-Service Quality: Definition, Dimensions and Conceptual Model. Cambridge, MA.

Zerenler, M. \& Öğ̈̈t, A. (2013). Sağlık sektöründe algılanan hizmet kalitesi ve hastane tercih nedenleri araştırmasi: Konya örneği. Journal of Chemical Information and Modeling, 53(9), 1689-99. 